\title{
Application of Garbage Complaints Monitoring Using the Prototype Method
}

\author{
Rio Jumardi \\ Sekolah Tinggi Teknologi Bontang \\ Bontang, Indonesia
}

\begin{abstract}
Utilization of mobile phone felt increasing with increasing community needs the latest information. Society as mobile phone users can utilize their mobile phones for a variety of needs including complaints against the government can provide. One complaint or report a social problem that can be given to the government of society is the garbage complaint. The trash problem as one of the environmental problems can be referred to as a social problem that needs to be regulated because it affects the lives of vast masyarakatl as it is said that the environment is a factor supporting human life. If the waste is disposed of carelessly, it will cause various health problems in the community. This application is expected to be able to facilitate the community to provide complaint reports about the garbage they have encountered around them to the authorities who are authorized quickly, easily and resolved.
\end{abstract}

Keywords: Application, Garbage, Mobile, Prototyping, Society.

\section{INTRODUCTION}

The development of information technology has a significant impact on every layer of community life, both individually and in organizations that causes information technology investment to become important and produce quality improvements from the information technology produced. At present, the application of information technology has developed rapidly not only in information technology based on websites and desktops but also on cellular based.

The development of cellular telephone telecommunications technology has progressed very rapidly, resulting in many changes that occur in people's lives, changing human lifestyles into easy and practical ways. Utilization of mobile phone felt increasing with increasing community needs the latest information.

Cellular phones today are no longer a luxury item. The use of cellphones has become increasingly widespread among the public. Society as mobile phone users can utilize their mobile phones for a variety of needs including complaints against the government can provide. The complaints or reports they provide are based on social problems encountered in the community. One of the complaints or reports of social problems that the people can give to the government is about garbage complaints.

The problem of waste as one of the environmental problems can also be said as a social problem that needs to be regulated because it affects the lives of the wider community as it is said that the environment is a supporting factor for human life [1]. Waste can have a negative impact on health if it is not addressed. If the waste is disposed of carelessly, it will cause various health problems in the community. Thus a more effective way is needed to improve communication between the community and the government related to the waste report.

The prototype of Garbage complaints reports monitoring is expected to be able to facilitate the community to provide complaints and complaints about the garbage they have encountered around them to the authorities who are quick, easy and resolved and can assist the government in monitoring waste complaints so the government can quickly overcome the problem that is.
According to Davis and Cornwell (2008: 737) explained that the word solid waste is a word commonly used to describe something we throw away. Solid waste, which consists of various objects that have been disposed of, contains various kinds of zar, which can be dangerous or not dangerous. However, in general, solid waste that accumulates can have a serious impact on dense human populations [1].

Waste must be managed properly until it is as small as possible so as not to disturb and threaten public health. Good waste management, not just for health purposes, but also for the beauty of the environment. Waste management includes collection, transportation, and destruction or waste management in such a way that the waste does not disturb the health of the community and the environment. Ways of managing waste include [1]:

a. Collection and transportation of waste Garbage collection is the responsibility of each household or industry that produces waste.

b. Destruction and Waste Management. Destruction and / or management of solid waste can be carried out in various ways, including: Landfill, Inceneration, Composting, Pulverization, Hogfeeding, Recycling.

This research use UML as a modeling procces. UML is a unit of modeling language developed by Grady Booch namely the Object Modeling Technique (OMT) and Object Oriented Software Engineering (OOSE). The Booch method is known as the Oriented Object Design method.

OMT modeling developed by Rumbaugh is based on structured analysis and entity-relationship modeling. The OOSE method of Jacobson emphasizes the use case. With UML mtode Booch, OMT and OOSE are combined. If People talk about UML, then it refers to Grady Booch, Ivar Jacobson and Jim Rumbaugh as creators, and they are called the Three Amigos [2].

UML diagrams have the main objective to help project development teams communicate, explore design potential, and validate software architecture designs [3]. To design an application or system using UML. In general, tools that can be used in designing UML-based systems consist of Usecase Diagrams, Activity Diagrams, Sequence Diagrams and Class Diagrams [4]. 
Monitoring that can be explained as an awareness of what you want to know, high level monitoring is done in order to make measurements through time which shows movement towards the destination or away from it [5]. Monitoring is generally carried out for specific purposes, to examine the following processes of objects or to evaluate conditions or progress towards the objectives of management outcomes for the effects of actions of several types including actions to maintain ongoing management. Monitoring will provide information about status and the tendency that measurements and evaluations are resolved over time [6].

Monitoring is a routine process of collecting data and measuring progress on program objectives, monitoring changes that focus on processes and outputs. Monitoring provides basic data to answer problems while evaluation positions these data so that they can be used and are expected to provide added value.

Monitoring is defined as a cycle of activities that includes the collection, review, reporting, and action of information on a process that is being implemented. Generally, monitoring is used in checking between performance and predetermined targets [7].

In its implementation, monitoring is carried out when a process is underway. The level of study of the monitoring system refers to activities per activity in a section, the indicator that is a reference for monitoring is output per process / per activity [7].

A prototype is an early version of a software system that is used to demonstrate concepts, design experiments, and find more problems and possible solutions. The prototype system allows users to know how the system is running properly [8]. There are 4 main prototyping methodologies, namely [9]:

1. Illustrative, produces an example report and screen display.

2. Simulated, simulates several system workflows but does not use real data.

3. Functional, simulates some actual system alaur and uses real data.

4. Evolutionary, produces a model that is part of the operational system.

Prototyping starts with gathering needs, involving system developers and users to determine system objectives, functions and operational needs. The steps in prototyping are as follows [9]:

1. Collection of Needs.

2. Fast design process.

3. Build a prototype.

4. Evaluation and improvement.

\section{RESEARCH METHODS}

Data collection methods used in this study are:

1. Literature Study

Literature study in this study comes from previous studies that can be used as a reference for this research material.

\section{Field Study}

Collecting garbage points and other locations that have the potential to accumulate garbage. The required point is the latitude and longitude coordinates and digital documentation.

The data analysis process is using the Prototyping system development method. The result of the data analysis is to produce a prototype of garbage complaints reports monitoring application.

The stages of system development or prototyping software methods consist of: Identification of system requirements, development of system prototypes, testing and revision or modification of prototypes made, and system development and maintenance.

\section{RESULTS AND DISCUSSION}

a. Designing Process Models

In modeling the process of garbage monitoring application based on mobile, the prototyping method is made in 2 model forms, namely use case diagram and activity diagram.

Use case diagrams show the interaction between users and the system built. In the design it can be seen that there are 5 cases of interaction between users and systems, namely login, new complaints, complaint lists, profiles, about applications.

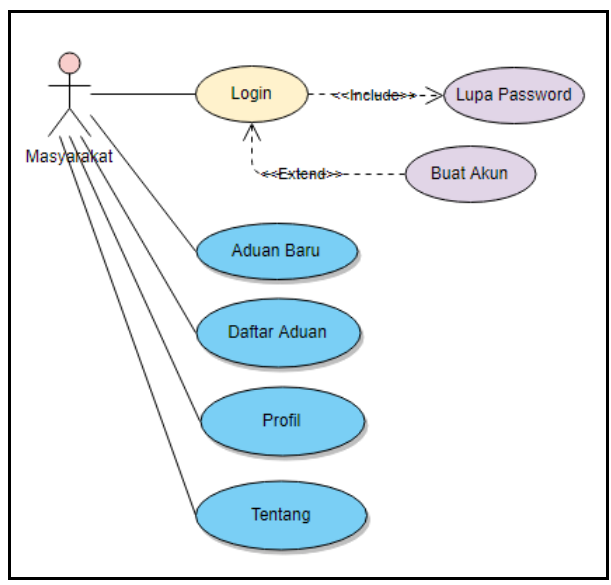

Figure 1. Use case Diagram

Activity diagrams show the activities that occur in the program to the process that takes place.

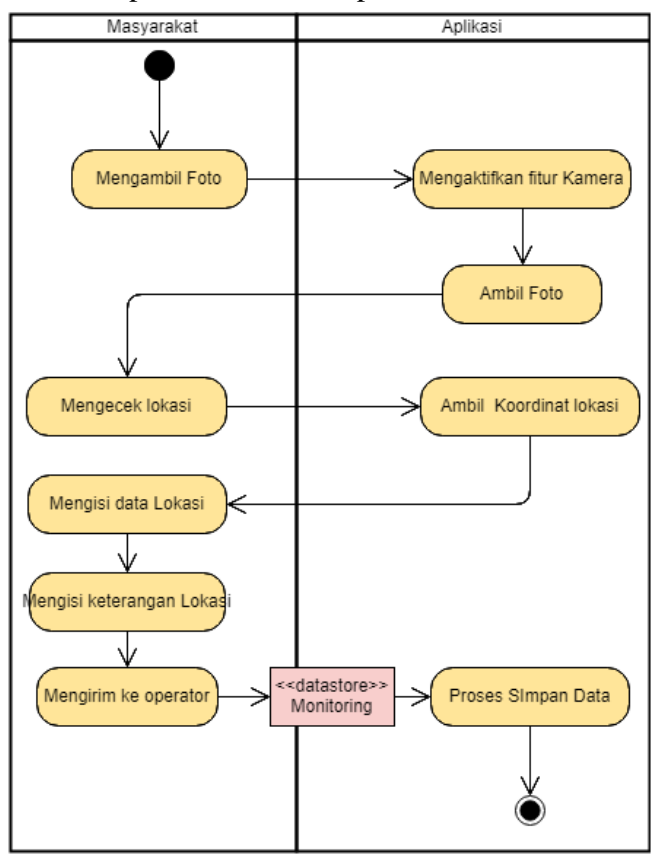

Figure 2. Activity Diagram of New Complaint

Activity Diagram of new complaints is the process of submitting a new complaint made by the people by utilizing the camera feature to record the location of garbage dumps. Then the location coordinates will be checked to be sent to the government operator.

b. Implementation 
After the system needs identification phase and process modeling, the next step is to make the application prototype in accordance with the UML design diagram that has been made.

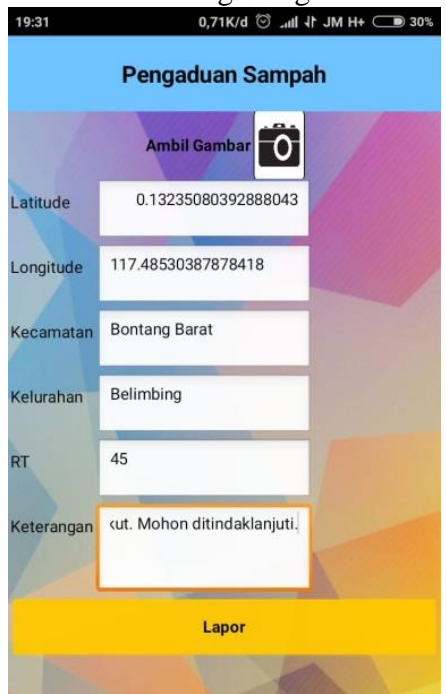

Figure 3. New Complaint Page

The new complaints page is a page where people provide reporting or garbage complaints that they encounter in the surrounding environment. The image and location of the trash that becomes a complaint will be sent to the operator in this case the city government to take action against the report.

The workings of this page are people taking pictures of the location of the trash that is a complaint. Then the community complements other data such as the coordinates of the reporting location, and information as perceived complaints. After that the data is sent to the server where the city government operator reads the report sent by the peoples.

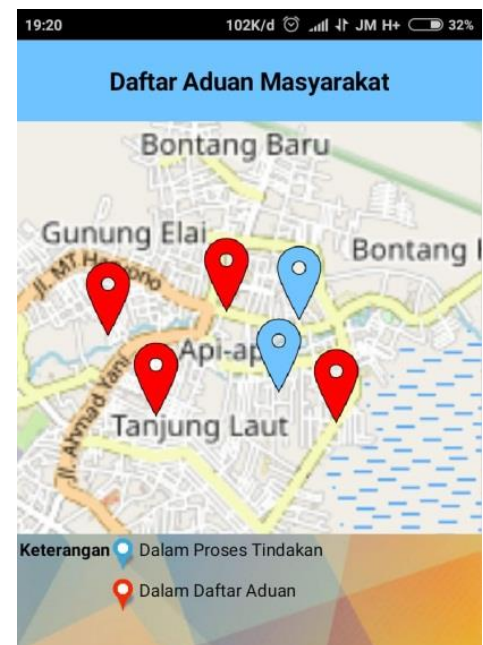

Figure 4. List of Peoples Complaint Locations

A public complaint list page is a page that can be used by application users to see where the location is a list of complaints reported by the public.
On this page there is a map of the location points of community reports. In the map there is a point that is represented by a different color icon with a description, the navy blue is used to mark the location that has been or is in the process of action by the city government on community reports while the icon is red to indicate the location where the public complaint has not been followed up or still on the public complaint list.

\section{CONCLUSION}

The conclusion in this research is:

a. This application is expected to be able to facilitate the community to provide complaint reports about the garbage they have encountered around them to the authorities who are authorized quickly, easily and resolved

b. The city government that gets complaints or reports from the public can monitor the location of the points that become complaints by the peoples.

\section{REFERENCES}

[1] Nur Rahmawati Sulistiyorini, Rudi Saprudin Darwis, and Arie Surya Gutama, "Community Participation in Waste Management in Margaluyu Environment, Cicurug SubDistrict," Share Social Work Jurnal, vol. 5, no. 1, Juli 2015.

[2] Rosa A. S. and M. Shalahuddin, Rekayasa Perangkat Lunak Terstruktur dan Berorientasi Objek. Bandung: Informatika, 2015.

[3] Haviluddin, "Memahami Penggunaan UML. Unified Modelling Language," Jurnal Informatika, vol. 6, no. 1, Februari 2011.

[4] Ade Hendini, "Pemodelan UML Sistem Informasi Monitoring Penjualan dan Stok Barang (Studi Kasus: Distro Zhezha Pontianak)," Jurnal Khatulistiwa Informatika, vol. 4, no. 2, pp. 107-116, Desember 2016.

[5] Gentisya Tri Mardiani, "Sistem Monitoring Data Aset dan Inventaris PT. Telkom Cianjur Berbasis Web," Jurnal Ilmiah Komputer dan Informatika (KOMPUTA), vol. 2, no. 1, pp. 35-40, Maret 2013.

[6] R. Jumardi, "Aplikasi Mobile untuk Monitoring Pendidikan Siswa Berbasis Android," http://repository.upnyk.ac.id/5107/, 2013.

[7] Tryawan Hendra Septian, "Rancang Bangun Aplikasi Monitoring Jamaah Haji Berbasis Mobile Android," UIN Alauddin, Makassar, Skripsi 2016.

[8] Afghan Amar Pradipta, Yuli Adam Prasetyo, and Nia Ambarsari, " Bojana Sari E-Commerce Web Development Using the Prototype Method " e-Proceeding of Engineering, vol. 2, no. 1, pp. 1042-1055, April 2015.

[9] Peter M Ogedebe and Babatunde Peter Jacob, "Software Prototyping: A Strategy to Use When User Lacks Data Processing Experience," ARPN Journal of Systems and Software, vol. 2, no. 6, pp. 2019-224, June 2012. 